\title{
漁業地域人口の構造を支配する要因
}

一人口の移動と世带規模に基づく観察——

\author{
松.山 恒 明* 鈴 木 継 美**
}

\section{Some Factors exerting an Influence on Composition in Fishery Zone in Miyagi Prefecture}

\author{
Tsuneaki KATSUYAMA* and Tsuguyoshi SUZUKI**
}

In Miyagi Prefecture, administrative regions were classifiable into three groups according to the relative proportion of workers engaging in agriculture, fishery or forestry in the total economically active population (SUZUKI and MATSUYAMA, 1974). The different pattern on some indices of population structure and growth including fertility, population decrease, and ratio of population aged 65 and over to that aged 0-14 years old was observed in fishery zone by comparing with other areas.

All these phenomena implied that young adults in fishery zone had different attitudes to migration from that of other area where agriculture is the most prevailing industry in the area. Because no available data on age-specific numbers of migrants was in the official mobility statistics, we devised the fluctuation ratio of regional population for analysis of the mobility. The term; fluctuation ratio was defind as a notation : $\mathrm{P}_{\mathrm{x}} / \mathrm{P}_{\mathrm{x}+5}$ $\left(P_{x}:\right.$ Number of regional population of $x$ years old in 1965 census, $P_{x+5}:$ Number of $x+5$ years old population in 1970 census in the same region). Since this fluctuation ratio changed by death and migration, age-specific death rates from 10 to 19 years of age tested, because the person of this age-group was exposed to migration to the greatest extent, but no correlation was found between death rates and rates of population in primary industries to total.

Young adults of this age group were less migratory in fishery zone than in other area in both sexes. This was likely to be resulted from the difference of the demand for young labor force in each area, and this might also bring about disparity of family sizes. By the census of fishermen and cultivators, the size was the greatest in the household engaging mostly in aquiculture of sea-weeds and shellfish, the second greatest in the household of

* 宮城教育大学, 保健管理センター

** 東北大学医学部公衆衛生学教室

* Miyagi University of Education

** Department of Public Health, Tohoku University School of Medicine 
agriculture, and the smallest in the household of non-tidal fishery. Thus, the requirement of young labor force was considered to differ even in the household of fishery, and by that reason, it is necessary to further elucidate the difference in fertility and migration depending upon various types of fishery.

\section{I はじめに}

一つの土地に人々が移り住む，むるいはそこを 去って行く過程には，数多くの要因が関与するこ とは疑いない，人の移動にかかるこれらの要因を 吟味する上で，筆者らは前に地域の人口棈造ある いは出生力の分析を行なったが，その場合と同じ く, ここでも土地の自然的条件と Subsistence Economy との交互作用1を基盤として観察を行な 万立場をとっている. 即ち，その土地に住む人々 の生業の内容を問題としてとり上げ，地域人口の 就業構造の中で，土地の直接的制約をうける職業 の割合を観察の基礎においている.

具体的には，既報においては22,3)，第 1 次産業 の内容別 (農林漁業) に地域をとりわけて，人口 構造や出生力の特徴を地域別に観察した。 この分 析から，宮城県域については，人口流出の影響が 比較的小さく，出生力抑制の進んでいないことと 相まって，人口老龄化が相対的に進んでいない漁 業地域と, 出生力抑制が進展し，人口流出も大き い農業を中心とするその他地域にわけて考えるこ とが出来るとの結果を得ている.

上記の分析における人口移動は，宮城県内の各 市町村別に1965年から1970年にかけての人口変動 総数をとり，1965年人口に 対する割合を求めて, 人口の増加，減少地域を全県的に観察したもので あるが，本報告においては，漁業地域を中心に人 口移動の主力となる年齢層の移動状況とこれに関 連すると考えられる世帯規模の問題について，主 に国勢調查と人口移動統計を用いて観察を行な 5 .

\section{II 資 料}

各市町村ごとの人口については，1965年及び 1970年の国勢調査結果 ${ }^{4}$ を，人口移動数について
は，1965～69年の住民基本台帪にもとつくく人口移 動報告の宮城県分 (5) を用いた。 各市町村の死亡数 は宮城県衛生統計年報1968～72年 ${ }^{6)}$, 農林水産関 係の資料は，第 4 次漁業センサスの宮城県分 ${ }^{7}$ 及 び1970年世界農林業センサスの宮城県分8)を用い た.

\section{III 結 果}

\section{1. 宮城県における社会移動}

住民基本台帳に基く移動報告として公表されて いる数值を用いて算出した宮城県における昭和 40 ４4年合計の普通純移動率（社会移動率—人口 1,000対）を図1に示す。率算出に用いた人口

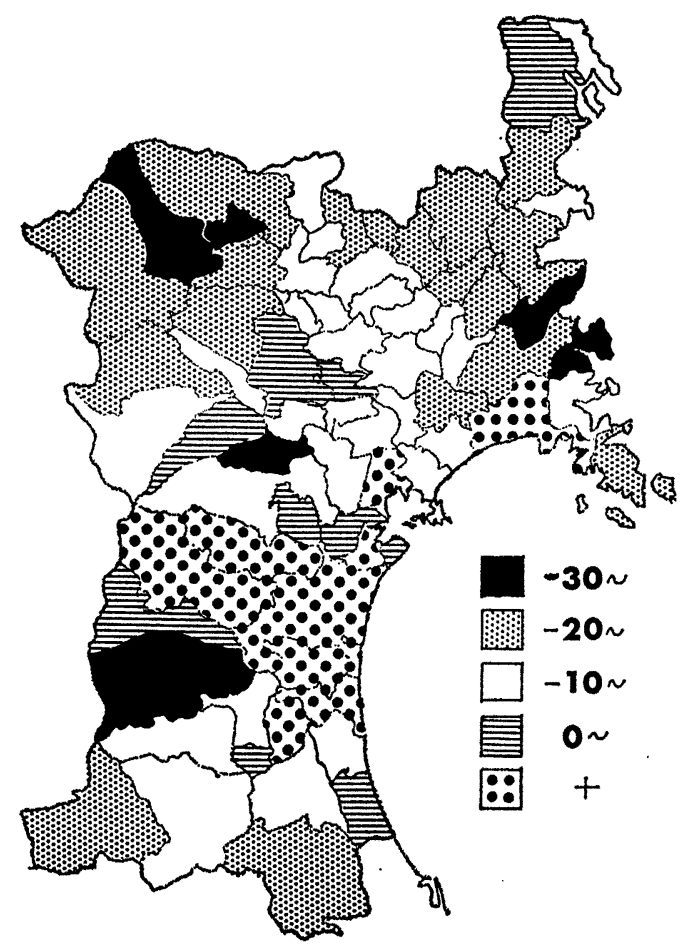

図 1 普通純移動率 宮城県 $40 \sim 44$ 年 率: 人口 1,000 対 
は，期初（昭和 40 年）の各市町村別国勢調査人口 である。移動報告に記載された数值のうち, 職権 記載及び消除については各資料の計算には加え ず，転入又は転出と表記されたもののみを用い た.

移動統計については, 転入・出届出時点の問 題, 職権による記載, 消除の問題等があり, 機械 的に計算を行ない率を求めることには問題がある が，ここでは大略の傾问を知る目的で率を算出し た。

罒にみる様に，仙台市並びにその周边地域と， 海岸部の一部市町で移動率が正の值をとり，移入 が移出より大であることを示すほかは，県内全域 にわたり，移出が移入を上迴り，人口減少傾向を 示している. 特に県北の山間部，三陸海岸沿いの 地域，県南の山間部にその率が大きな町村を認め る.

\section{2. 人口変動比による観察}

人口移動について，地域の産業特性に基いて観 察を行うために，既報3) と同じく，地域ごとの男 女計15才以上就業者中の第 1 次産業就業者割合 （以下「第 1 次割合」とす）において，農業以外 の第 1 次産業が一定割合以上を占める市町村を, 農業中心の「その他地域」から区別し，「三陸漁業 ベルト地域」「山村地域」とする（ここでいう漁 業ベルト地域とは，漁業従事者割合が1970年国勢 調查において，全就業者の $4 \%$ \%越えている地域 を指すなおむの数值は便宜的なものである，漁 業ベルト地域については既報るをを参照されたい)． 図 2 に宮城県における市町村別「第 1 次割合」を 示す。

さて，人口移動統計においては，年齢階級別の 移動数が発表されていないが，「第 1 次割合」の高 い地域よりの移出の主力は若年労㗢力であり, 又 就学のための移動がこれに加わるであろうことは 想像に難くない，そこで，年齢別コホートにおけ る人口移動の問題を検討するため，次の方法を考 えた。

相続く 2 つの国勢調査年次（ここでは昭和 40 年 と45年) 間の年齢別コホートの比, 即ちあとの調

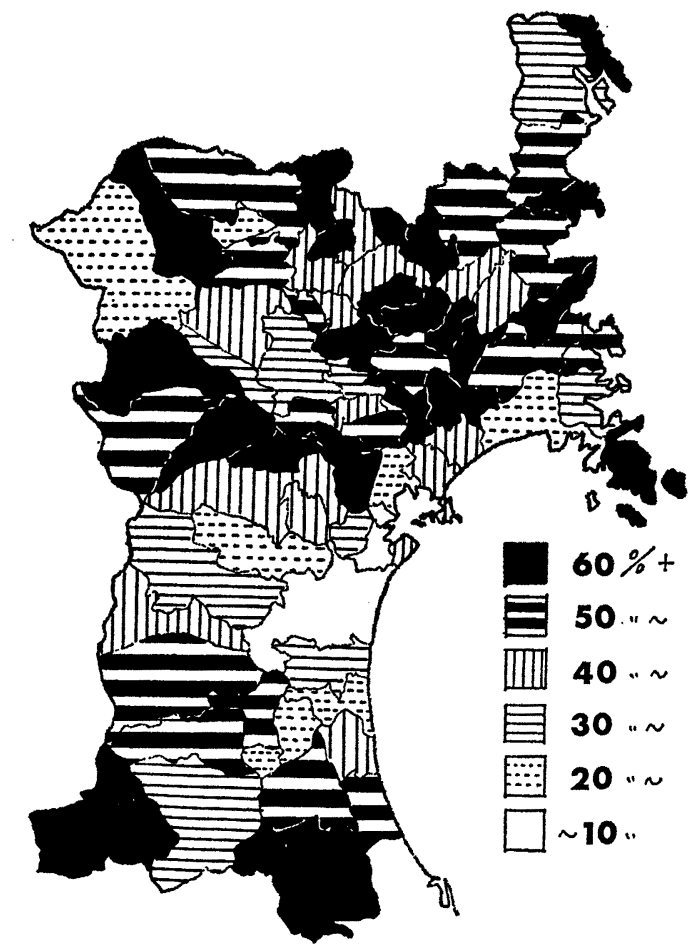

図 2 市町村別第 1 次産業就業者割合 昭和 45 年 宮城県

査年の $\mathrm{x}+5$ 才人口を，前の調査年の $\mathrm{x}$ 才人口で 割った值を算出し，これを人口変動比とする. 次 に前述の三区分, 即ち「漁業ベルト地域」「「山村 地域」「その他地域」について，「第 1 次割合」別 に市町村を分類し，上述の方法で算出した各年齢 階級の人口変動比を描図した.

図 3，4，5飞「第 1 次割合」別人口変動比を 示す．横軸に年齢，縦軸に人口変動比をとってあ る. 人口変動比は 1.0 を境にして, 1.0 より比の数 值が小さい場合は，この 5 年間にある年齢別コホ 一トに人口減少が，大きい場合には人口増加があ ったことを示す、「第 1 次割合」これは「その他 地域」に求いてはほとんど農業就業者割合と一致 すると考えてよい）は，人口流出についての検討 を目的としたため，30\%をでを図示した．尚， $20 \%$ 以下では若年層の人口增加傾向が顕著とな る.

三地域とも10１4才，(昭和40年に10〜14才であ 


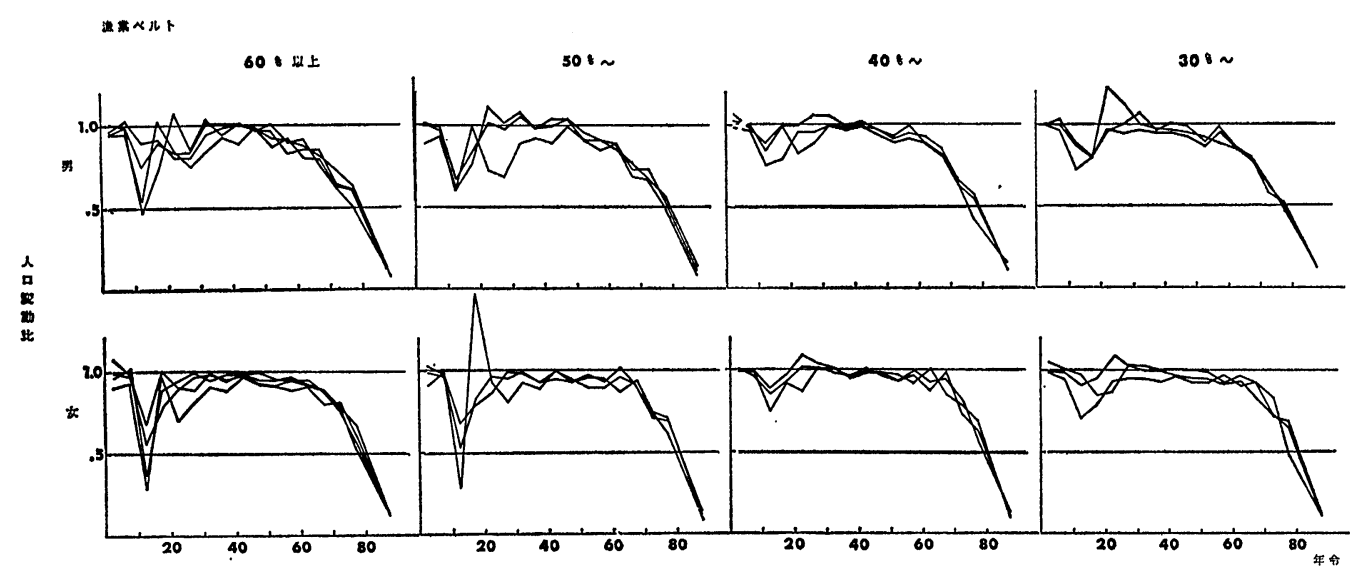

図 3 第 1 次産業就業者割合別人口変動比, 昭和 45 年 一漁業ベルトー

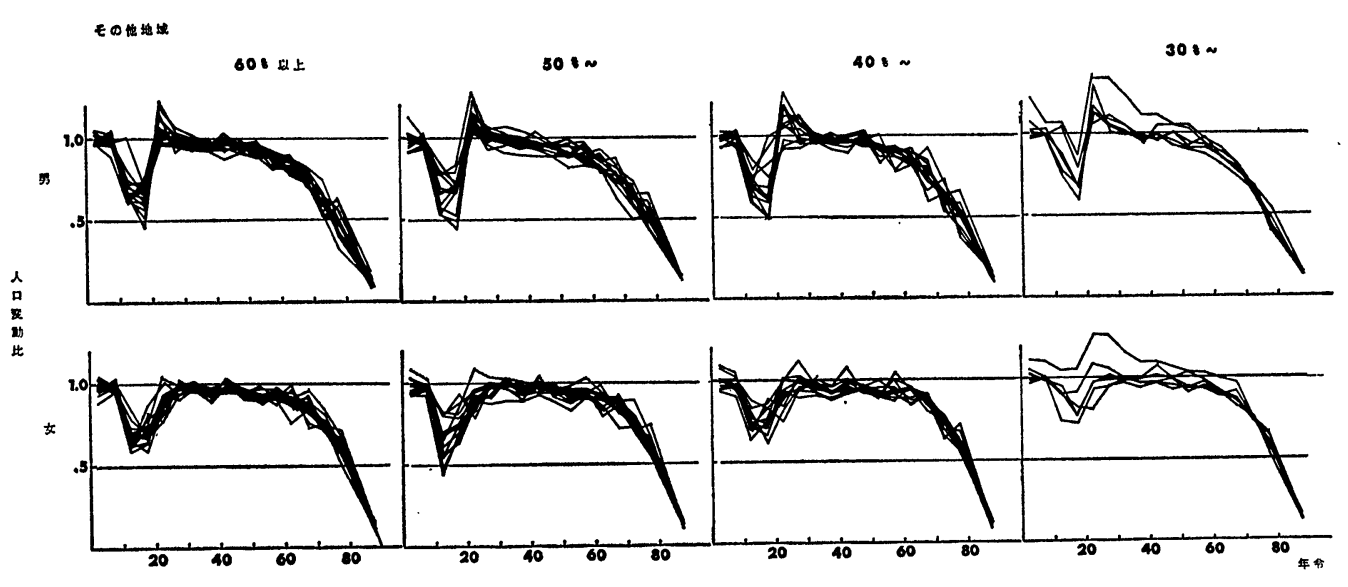

図 4 第 1 次産業就業者割合別人口変動比, 昭和 45 年 一その他地域一

った者，以下同）15〜19才の年齢において，男女 ともに人口減少を示す深い谷がみられる，人口の 減少傾向は，「山村地域」においてもっとも著るし い. 一方, 男の「その他地域」20２4才では人口 增加を示す山が認められる.

「漁業ベルト」と「その他地域」とでは，「第 1 次割合」の減少と, 若年者の人口変動比の動向が 異なる傾向が認められる. この点を検討するため に，若年齢層の各年齢階級別に人口変動比々「第 1 次割合」その 1 次及び 2 次の 回帰式を算出し,
回帰線の適合度を調べた. 垁測值と 1 次及び 2 次 の回帰式より得られた理論値間の相関係数によっ て，相関係数の値がより大きい方を採用して図示 したものが図 6 である. 回䢴式及び相関係数は表 1 に示す.

10〜14才についてみると，回帰直線の方が良く 適合するのは「漁業ベルト」の女子のみで, 他は 2 次回帰の適合度が高い. 即ち, 「漁業ベルト」で は, 「第 1 次割合」の変化と女子の人口減少は平行 的である. 
山村

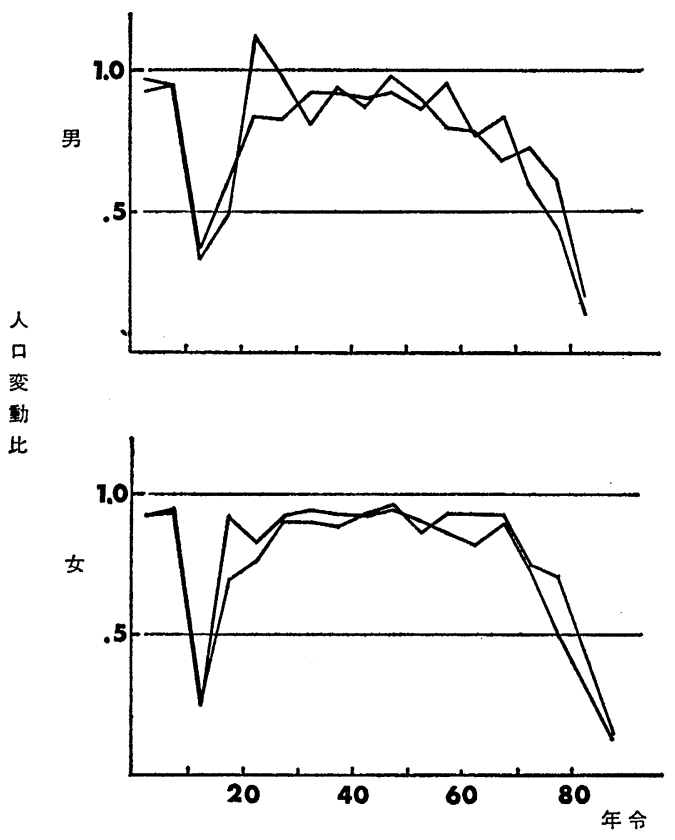

図 5 第 1 次産業就業者割合別人口変動比, 昭和 45 年一山村一

更に15〜19才においては，「漁業ベルト」と「そ の他地域」との人口減少傾向は明らかに 異なり， 「その他地域」においては，男女とも，10１4才 の同地域の傾向とよく似ているが，「漁業ベルト」 では，むしろ「第 1 次割合」の高い方で人口減少 が少なくなる傾向を示す，但し，適合度には有意 性がなく，各市町村により，状況に差異のあるこ とがうかがわれる。「その他地域」男子の上記 2 年 齢階級では，「第 1 次割合」50\%でもっとも人口減 少が著るしい。

「その他地域」の20〜24才，25〜29才では，男 の回帰線は変動比 1.0 を越えており，この 5 年間 に人口增加が生じたことを示している，この年齢 層の男子人口の地域への還流が考えられる.

3. 人口指標之平均世帯員数

「漁業ベルト」における若年齢層，特に15１9 才人口の変動が，農業を中心とする「その他地域」 のそれと異なっていることは，各種の人口指標や
世帯員の数に反映していると考え得る. これらの 地域における全人口についての各種人口指標の比 較検討はすでに報告したが3)，ここでは，「漁業へ ルト」,「その他地域」を特徵付けている漁業並び に農家世帯を中心に若干の人口指標と平均世帯員 数について比較検討する.

第 4 次漁業センサス及び1970年世界農林業セン サスの宮城県分には，各市町村についての農業並 びに漁業世帯の年龃階級別世帯員数が発表されて いる。調查年次が漁業センサスは昭和 43 年，農林 業センサスは昭和 45 年であり， 2 年のずれがある が，若干の人口指標と平均世带員数について大略 の傾向を知るため数值を算出した。

表 2 飞「漁業ベルト」及び「第 1 次割合」別の 「その他地域」についての三種の人口指標を示 于.

各市町村の全世帯及びこれら地域内の農家並び に漁業世带（個人経営体一海面漁業を営む個人 の漁業経営体一のみ) について，15６0才人口 に対する 0 ～14才人口の割合（年少人口指数）, 15〜60才人口に対する 60 才以上人口の割合（老年 人口指数)，０～14才人口に対する 60 才以上人口 の割合（老年化指数）が算出してある. 全世帯の 数值計算には昭和 45 年の国勢調査結果を用いた. これらの指数を算出する場合，老年人口は65才以 上とするのが通例であるが，ここでは資料におけ る年齢区分の関係から，通常とは異なった区分を 用いている.

表にみるごとく，「漁業ベルト」においては，全 世带, 漁業世帯共に「その他地域」の全世帯, 農 家世带に比して年少人口指数が高く，老年化指数 が低い.

前述の資料により，一世带当りの平均世帯員数 を農家及び漁業世帯について算出した。漁業世帯 は経営形態と雇用関係から 個人経営体と漁業従事 者世带（海面漁業に従事するもののいる世帯）に わけて計算した。

图 7 に「第 1 次割合」別の農家及び漁業世帯の 平均世帯員数を各市町村について示す。罒にみる ごとく, 全般に個人経営体世帯の 1 世帯当り人員 


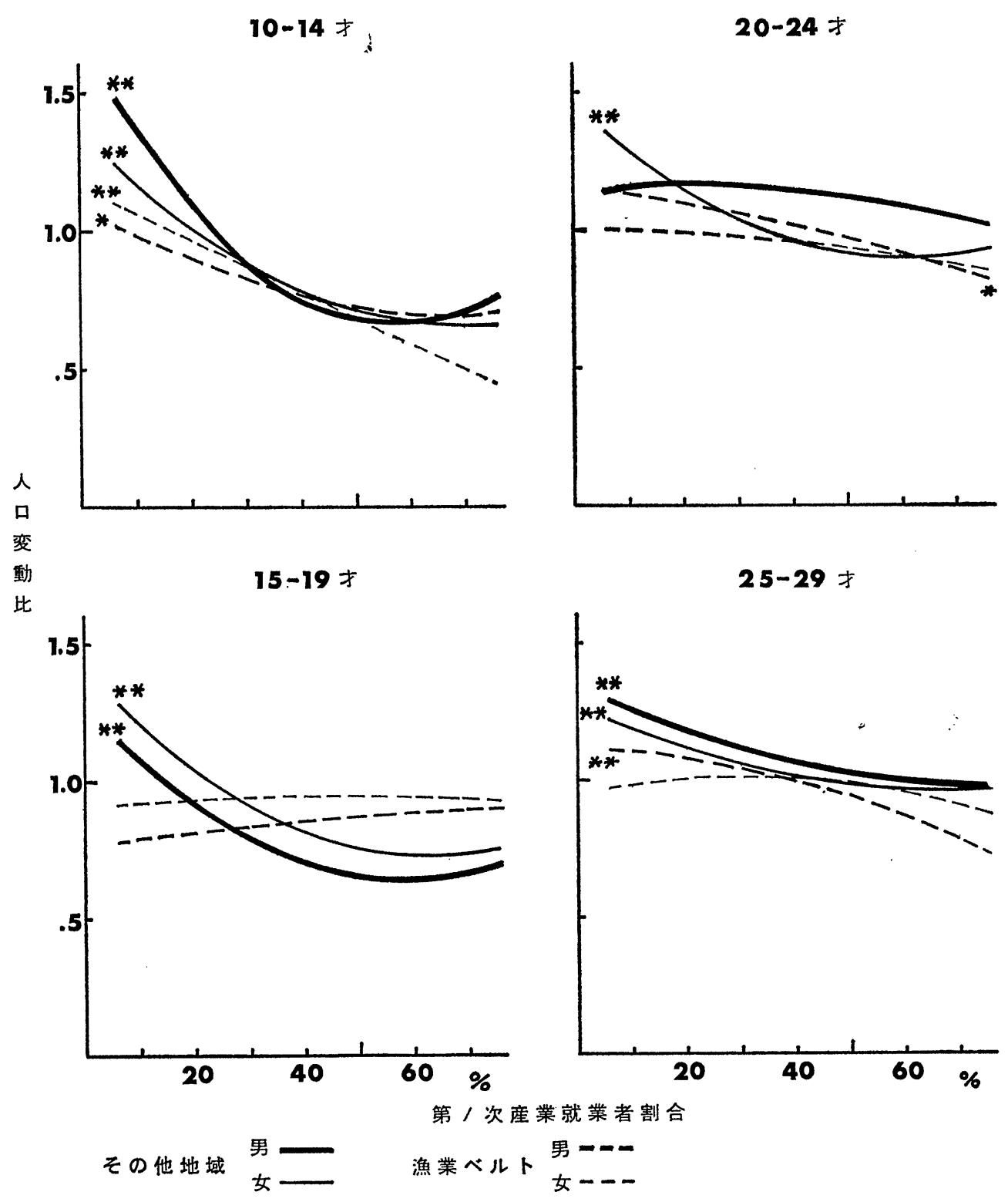

図 6 第 1 次産業就業者割合別, 年令別人口変動比, 昭和 45 年 その他地域及び漁業ベルト 
表 1 人口変動比と第 1 次産業就業者割合

\begin{tabular}{|c|c|c|c|c|c|}
\hline & \multicolumn{2}{|l|}{ その他 地 域 } & \multicolumn{2}{|l|}{ 漁 業 ベルト } \\
\hline & & $\begin{array}{l}\text { 人口変動比 }(\mathrm{Y}) \text { と第 } 1 \text { 次産業 } \\
\text { 就業者割合 }(X) \text { との関係 }\end{array}$ & $\begin{array}{l}\mathrm{X} \text { と } \mathrm{Y} \\
\text { 相関係数 }\end{array}$ & $\begin{array}{l}\text { 人口変動比 }(\mathrm{Y}) \text { と第 } 1 \text { 次産業 } \\
\text { 就業者割合 }(\mathrm{X}) \text { との関係 }\end{array}$ & $\begin{array}{l}\mathrm{X} \text { と } \mathrm{Y} \\
\text { 相関係数 }\end{array}$ \\
\hline \multirow{2}{*}{$10 \sim 14$ 才 } & 男 & $\mathrm{Y}=3.22 \mathrm{X}^{2}-3.69 \mathrm{X}+1.72$ & $0.753^{* *}$ & $\mathrm{Y}=0.64 \mathrm{X}^{2}-1.02 \mathrm{X}+1.08$ & $0.604^{*}$ \\
\hline & 女 & $\mathrm{Y}=1.52 \mathrm{X}^{2}-2.09 \mathrm{X}+1.37$ & $0.724^{* *}$ & $\mathrm{Y}=-0.98 \mathrm{X}+1.17$ & $0.736^{* *}$ \\
\hline \multirow{2}{*}{ 15〜19才 } & 男 & $\mathrm{Y}=1.86 \mathrm{X}^{2}-2.18 \mathrm{X}+1.28$ & $0.583^{* *}$ & $Y=-0.17 X^{2}+0.31 X+0.76$ & 0.349 \\
\hline & 女 & $\mathrm{Y}=1.69 \mathrm{X}^{2}-2.15 \mathrm{X}+1.40$ & $0.668^{* *}$ & $\mathrm{Y}=-0.17 \mathrm{X}^{2}+0.18 \mathrm{X}+0.90$ & 0.062 \\
\hline \multirow{2}{*}{ 20〜24才 } & 男 & $\mathrm{Y}=-0.41 \mathrm{X}^{2}+0.13 \mathrm{X}+1.15$ & 0.277 & $Y=-0.25 X^{2}-0.25 X+1.16$ & $0.559^{*}$ \\
\hline & 女 & $\mathrm{Y}=1.57 \mathrm{X}^{2}-1.91 \mathrm{X}+1.46$ & $0.528^{* *}$ & $\mathrm{Y}=-0.31 \mathrm{X}^{2}+0.05 \mathrm{X}+0.99$ & 0.430 \\
\hline \multirow{2}{*}{ 25〜29才 } & 男 & $\mathrm{Y}=0.51 \mathrm{X}^{2}-0.88 \mathrm{X}+1.34$ & $0.437^{* *}$ & $Y=-0.56 X^{2}-0.04 X+1.10$ & $0.716^{* *}$ \\
\hline & 女 & $\mathrm{Y}=0.73 \mathrm{X}^{2}-0.97 \mathrm{X}+1.28$ & $0.398^{* *}$ & $Y=-0.62 X^{2}+0.38 X+0.94$ & 0.478 \\
\hline
\end{tabular}

* 危険率 $5 \%$ で有意 ** 危険率 $1 \%$ で有意

表 2 地域別並びそ農業, 漁業別の人口指標

\begin{tabular}{|c|c|c|c|c|c|c|c|c|}
\hline & \multicolumn{2}{|c|}{ 漁業 ベルト } & \multicolumn{6}{|c|}{ その他地域 (「第 1 次割合」別) } \\
\hline & \multirow{2}{*}{ 全 世 带 } & \multirow{2}{*}{ 漁業世带 } & \multicolumn{3}{|c|}{ 全 世 帯 } & \multicolumn{3}{|c|}{ 農 家 世 带 } \\
\hline & & & $60 \%+$ & $50 \%-$ & $40 \%-$ & $60 \%+$ & $50 \%-$ & $40 \%-$ \\
\hline 年少人口指数 & 43.7 & 46.7 & 39.8 & 40.6 & 42.8 & 39.3 & 41.8 & 40.3 \\
\hline 老年人口指数 & 18.8 & 23. 8 & 22.1 & 21.8 & 20.9 & 23.7 & 25.0 & 24.4 \\
\hline 老 年 化 指 数 & 42.8 & 50.1 & 55.6 & 55.0 & 51.9 & 60.5 & 60.4 & 60.8 \\
\hline
\end{tabular}

註1. 漁業世带のみ昭和 43 年, 他は昭和 45 年の資料による

註2. 資料の年令区分の関係上, 各年令階層は0〜14才, 15〜60才, 60才以上で算出した.

がもっとも多く, ついで農家世带, 漁業彷事者世 带の順になる。漁業世带では「第 1 次割合」の増 加と共に世带規模も大きくなるが，農家世带では このような傾向はみられない.

\section{IV 考察}

宮城県内の漁業地域を対象に，その人口構成に 影響すると考えられる要因の中から，人口移動と 世带規模をとり上げ，農業中心の「その他地域」 と比較しながら，若干の分析をおこなった。

地域人口変動の一要因としての人口移動につい
ては，戦後のわが国における大規模な，農村一 都市間移動に関連して数多くの報告が行なわれて いる ${ }^{9)}$. 近代社会において，人口移動を促すもっ とも主要な要因として館は，生活水準の相対的格 差, 就業あるいは所属産業や職業転換, 就学など を上げているが ${ }^{10)}$ ，人口流出の顕著である農業地 域に，漁業が加わった場合，人口移動にどの様な 変化がみられるかが，筆者らの興味を持った事柄 である。

この分析を行な5については，館のい5人口移 動の促進要因からしても, 就学, 就職による移動 


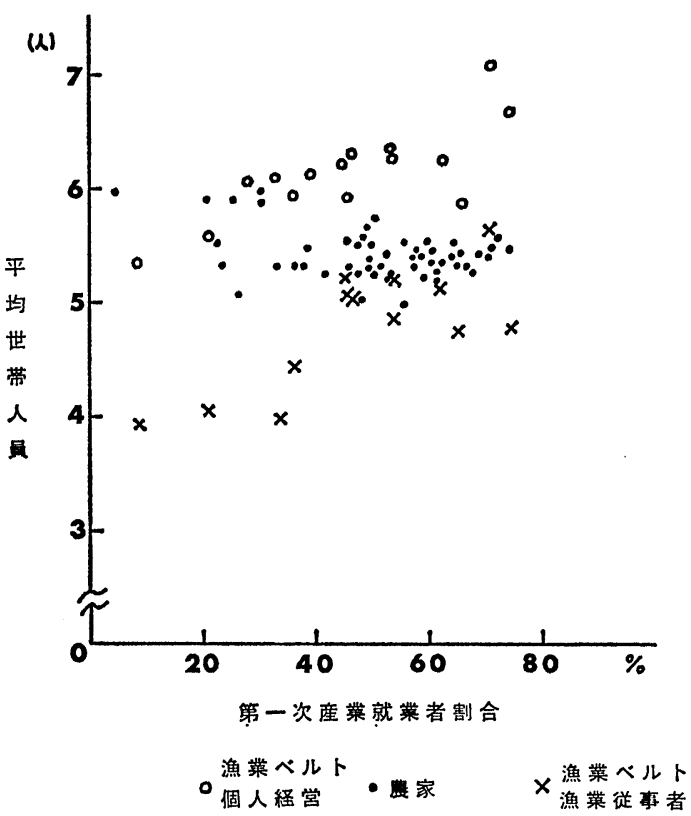

図 7 「第 1 次割合」, 別, 農・漁業別平均世带 員数，農家及び漁業世带

註：農業世带は昭和 45 年, 漁業世带は昭和 43 年の資 料による。

が多いとみこまれる，若年層を中心とした年龄階 級別の人口移動の検討が重要であることはいうま でもない。しかしながら，「住民基本台帳にもと つく人口移動報告一一宮城県」として公表されて いる資料には，市町村の年齡階級別移動数は発表 されておらず，別途の方法を考劣る必要がある.

そこでわれわれは，相続く 2 つ国勢調查年次 間の年齢別コホートの比一人口変動比をもって これにかえることとした．この人口変動比は仮谷 のい5人口推移率 ${ }^{111}$ と同じものであり, 基本的に は, 浜の交替指数 (replacement index-15〜 29才と0〜14才人口の比) ${ }^{12}$ にも相通ずるもので ある。

人口変動比は $\mathrm{x}$ 才口と 5 年後の $\mathrm{x}+5$ 才人口 の比であるから，その内容には，この 5 年間にお ける死亡による人口減少と, 流出・流入人口の差 とが統合されている，人口変動比を人口移動と 「第 1 次割合」との関連の一指標として用いよ5 とすれば，当然死亡について考虑しておかなけれ
ばならない。すでに発表したよ5に3)，宮城県に おいては各市町村別の「第 1 次割合」と粗死亡率 間には, 有意の順相関 $(+0.694, \mathrm{p}<0.01)$ が認 められる。

しかし前述の様に，われわれが人口変動比でも っとも問題としたのは10～19才における変化であ り，死亡の問題もこの年齢層でどの様に生ずるか にしぼられて来る。昭和40〜44年の 5 年間につい て，宮城県内各市町村の性別10～14才，15～19才 死亡数を合算したところ，10〜14才では半数, 15〜19才では約1/3の市町村において死亡率が0で あったそとで死亡者のあった市町村についての み，10～14才 及び 15～19才 の性別死亡率を算出 し，「第 1 次割合」との間で相関係数そ求めたが， いずれも有意の相関を示さなかった，以上の結果

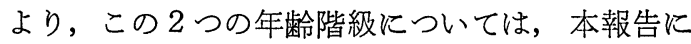
関するかぎり，死亡と「第 1 次割合」との間に平 行関係はないものと判断し，分析を進めた.

各年龄階級別に人口変動比をみた場合，「漁業 ベルト地域」の女子が直線回帰を示すことが注目 される，農村都市間移動の場合，女子の流出が男 子に比し優勢になると Hawley ${ }^{13)}$ は述べている が，「漁業ベルト」内の「第 1 次割合」高率地域で は，二つの年齢の女子において同様の傾向が認め られる. 15〜19才においては，「漁業ベルト」の人 口移動は明らかに「その他地域」と異り「第 1 次 割合」が高くなると逆に人口流出が少なくなる市 町村が含まれていることが認められる.

このよ5に人口変動比についてみるかぎり， 「漁業ベルト」では，10～19才とい5若年龄懕 で，女子の流出が男子に比し優勢な一部町村があ ること，農業主体の地域に比し相対的に若年齢層 の地域内残留の多い町村があることが明らかであ る.

「漁業ベルト」地域で若年人口流出が相対的に 少ない理由はなんであろらか.

まずこの地域を特徵付ける漁業という産業形態 が何らかの影響を与えている可能性がある. 結果 の部分で述べたように，「その他地域」内の農業世 帯に比し，「漁業ベルト」内の個人経営体世帶（昭 
和 45 年の資料によればその $75 \%$ 以上が 何らかの浅 海養殖業に従事している）では年少人口指数が高 く，老年化指数が低いことが示されている.

養殖業を主体とする個人経営体世带の労働が, 家族内労働力により維持されていることは，例え ば最盛期従事者数の $50 \%$ 以が家族内労㗢力であ ることからも推察されるが，このような労働形態 が大家族制度を存続させていく可能性のあること は首肯され得ることであろう。

多田 ${ }^{14)}$ は，われわれのいう漁業ベルト地域内の 1 漁村の調査から, 漁業経営と漁業労働が 分離 し, 更に労働力の提供者である漁夫，漁家層が自 立して個人経営体に移行して行った歴史的過程を 記述しているが，同じ漁業を営む世带の中で，漁 業の形態により，世带構成との他に違いの生じて 来ることは当然考光得ることである.

結果の項で示した様に，同一市町村内でも個人 経営体世带と, その $95 \%$ が沖合, 遠洋漁業に従事 する漁業従事者世带とでは，前者の世带規模が明 らかに大さい。

但し，平均世帯員数算出に用いた漁業センサス 資料は，世帯員の中に国勢調査の場合と同じく， 非血縁であっても単身の住込久者は世帯員に加光 ているため, 個人経営体の世带規模が若干拡大し ている可能性がある. 一方, 漁業従事者世帯につ いては，調查時に出漁で不在のものを申告せず， 従って世带規模が縮少した様な例を考劣ることも 出来る. もっとも, 同上世帯について，20才以上 世带員の性比を算出し，同地域内全世带のそれと 比較したが，差はみられなかった。

以上のように漁業世带については，世带規模に おいて, 二つの形態が存在するのであって，この ことが, 若年学働力の残留, 一部の核家族化と, その故の一時的，あるいは横断的観察にみられる 相対的な高出生力などを招来している可能性は否 定出来ない.

しかし同時に示した様に, 漁業ベルト内全世带 についての人口指数は, 漁業世带のそれよりも更 に高い年少人口指数，低い老年化指数を示してお り, 人口移動に拈ける漁業ベルト地域の特異性
は, 漁業形態の問題のみで説明しつくせるとは考 えられない。

一つの見方として，われわれのとり出した㵂業 ベルト地域が，宮城県における産業形態上特異な 地域であり，県内の大部分を占めている水田単作 農業地带に比し, 農業に漁業が加わり, 更に地方 小都市の点在による地域的商工業の核形成の行な われている地域であると考兄ることが可能であ る.

人口移動統計により，各市町村別に移動先市町 村を整理し，その移動量を順位付けしてみると， 漁業ベルト内の 3 つの市が地域内の人口移動にお いて，一つの目的地になっている様子がみられ $る^{15)}$.

今回の分析では，これら小都市が人口移動ある いは地域内の出生力に及ぼす影響についての考察 には及ばなかったが，この点について，今後更に 検討をすすめたい。

\section{$\mathrm{V}$ 結 語}

1. 宮城県内行政区域について，若年齢層の人口 移動を観察すると，15〜19才における地域内人 口残留が，「漁業ベルト」地域に相対的に高率で ある。

2. 漁業形態により世带規模を比較すると個人経 営体世帯に大家族的傾向が，漁業従事者世带に 核家族化傾向がみられ，いずれも若年労働力の 地域内残留, および相対的高出生力と密接な関 連を持つものと考えられる。

\section{文献}

1）鈴木継美：“生態学的仕組み” 飞ついて，保健婦雑 誌，29，192〜195（1973）

2）鈴木継美, 松山恒明：地域別出生力-1970年宮城 紧行政地域について，医学のあゆみ，89(7)，392〜 388 (1974)

3）鈴木継美, 松山恒明：地域人口の解析, 日本公衛 誌, 21(10)，561～567（1974）

4）総理府統計局：国勢調查報告, 都道府県, 市町村 編, 宮城県, 昭和 40 年, 昭和 45 年 
5）宮城県調査眯 : 本県の人口動態, 昭和 $40,41 ， 42$, 43,44 年

6）宮城県街生部：衛生統計年報，昭和 $43 ， 44,45$, 46, 47 年

7）宮城県調查琽 : 第 4 次漁業センサス結果報告書, (1970)

8）宮城県調査課：1970年世界農林業センサス，農家調 查結果概要 (1971)

9)例えば :

黒田俊夫 : 人口移動・分布のパターン, 医学のあゆ み, $85(13), 881 \sim 886$ (1973)

岡崎陽一・須田トミ：最近の人口移動に関する統計
的分析，人口問題研究，(124)，50〜61（1972）

10）館 稔：人口分析の方法，241, 古今書院 (1963)

11）仮谷太一：2つの国調人口にもとづく男女別年齢別 人口推移率の推定, 日本人口学会会報, 昭和 47 年度, 22〜23 (1972)

12）演 英彦：年齢構成括よび産業構成からみた地域人 口の特性, 人口問題研究，(118)，21３4（1971）

13) Hawley, A. H.; Human Ecology, 342 Ronald New York, 1950

14）舛田忠雄：三陸地方一遠洋漁村飞扣ける親族組織の 研究, 社会学評論, (75), 22〜 41 (1969)

15）松山恒明：未発表資料 